\title{
THE ROLE OF EXOGENOUS LIPIDS IN THE HYPERLIPEMIA AND HYPERCHOLESTEREMIA OF NEPHROTIC RATS ${ }^{1}$
}

\author{
BY MEYER FRIEDMAN, RAY H. ROSENMAN, AND SANFORD O. BYERS
}

(From the Harold Brunn Institute, Mount Zion Hospital, San Francisco, Calif.)

(Submitted for publication February 15, 1954 ; accepted April 17, 1954)

The renal disease, ascites, subcutaneous edema, and hyperlipemia induced in rats by injection of rabbit anti-rat kidney serum comprise a syndrome which closely resembles the nephrotic state as it occurs in humans (1). This provides a unique opportunity to study the mechanism(s) of the disturbed lipid metabolism of the nephrotic state. In previous studies from this laboratory it was found that the hypercholesteremia of nephrotic rats cannot be ascribed either to an increased intestinal absorption of dietary cholesterol (2) or to an increased hepatic synthesis of endogenous cholesterol (3). In the present study the role of exogenous lipids is further assessed, the data showing that the development of experimental nephrotic hyperlipemia and hypercholesteremia is independent of dietary fat.

\section{METHODS AND MATERIAL}

Twenty male rats (Long-Evans strain), were injected intravenously with $0.5 \mathrm{ml}$. of rabbit anti-rat kidney serum (1) on each of two successive days. Seven of the rats (Group I) were fed a fat and sterol-free ration for five days prior to injection of immune serum, and continued to ingest this ration. Eight rats were fed stock laboratory ration (Group II) and five others (Group III) ingested stock ration supplemented with cholesterol (2 per cent of the diet) and cholic acid (1 per cent of the diet). The cholesterol and cholic acid-supplemented diet also was fed to six normal rats (Group IV) which were not injected with anti-kidney serum. A fifth group of ten other control rats (Group V) were fed stock ration.

Each rat was bled from the tail six days after the injection of immune serum, and assay made according to previously described methods of the plasma concentrations of total cholesterol (4) and total lipids (5). Four days later similar determinations again were made in the rats ingesting stock ration (I) and the fat-sterol-free diet (II).

1 Aided by grants from the American Heart Association and research grant A-46 from the National Institute of Arthritis and Metabolic Diseases, National Institutes of Health, Public Health Service.
RESULTS

Six days after the administration of immune serum all of the injected rats exhibited ascites, and lipemic-turbidity of their plasma. Table I presents the averages and ranges of plasma total lipids and total cholesterol values obtained from the nephrotic rats fed stock ration (Group II), those fed the diet free of fats and sterols (Group I), and the normal rats fed stock ration (Group V). The data show that the rats fed the fat-sterol-free diet developed a degree of hyperlipemia and hypercholesteremia equal to, or slightly greater than that developed by the nephrotic animals ingesting stock ration. The nephrotic rats of both groups exhibited a similar degree of ascites, subcutaneous edema, and grossly apparent turbidity of the plasma samples.

The ingestion of a ration containing excess cholesterol and cholic acid has been shown to induce chronic hypercholesteremia in rats $(6,7)$, due to the increased intestinal absorption of cholesterol effected by simultaneous administration of cholate (8). The effect of ingesting this supplemented diet for six days upon the hyperlipemia and hypercholesteremia of nephrotic rats and of the plasma lipids of normal rats is presented in Table II. It can be seen that both the hyperlipemia and hypercholesteremia were of much greater magnitude in the nephrotic rats (Group III) fed the cholesterol and cholate supplement, than in the nephrotic animals fed stock ration without the supplement (Group II). The normal control rats which ingested the cholesterol and cholate supplement (Group IV) also developed a moderate rise of plasma total lipids and total cholesterol in this interval. However, the magnitude of the hypercholesteremia was of lesser degree than the difference observed in the nephrotic rats which ingested the supplemented diet (Group III) when the latter are compared with the nephrotic rats which were fed the stock ration 
TABLE I

Effect of sterol free diet upon development of hyperlipentia and hypercholesteremia of nephrotic rats*

\begin{tabular}{|c|c|c|c|c|c|c|c|c|}
\hline \multirow[b]{3}{*}{ Group } & \multirow[b]{3}{*}{ Type of rat } & \multirow{3}{*}{$\begin{array}{l}\text { No. of } \\
\text { rats }\end{array}$} & \multirow[b]{3}{*}{ Diet } & \multirow{3}{*}{$\begin{array}{c}\text { Average } \\
\text { weight } \\
\text { (Gm.) }\end{array}$} & \multicolumn{4}{|c|}{ Average plasma concentration (mg./100 cc.) } \\
\hline & & & & & \multicolumn{2}{|c|}{ Day 6} & \multicolumn{2}{|c|}{ Day 10} \\
\hline & & & & & Cholesterol & Total lipids & Cholesterol & Total lipids \\
\hline I & Nephrotic & 7 & $\begin{array}{l}\text { Fat and } \\
\text { Sterol free }\end{array}$ & 120 & $\begin{array}{c}196 \\
(109-266)\end{array}$ & $\begin{array}{c}968 \\
(291-1710)\end{array}$ & $\begin{array}{c}485 \\
(425-530)\end{array}$ & $\begin{array}{c}2073 \\
(1650-2700)\end{array}$ \\
\hline II & Nephrotic & 8 & $\begin{array}{l}\text { Stock } \\
\text { Ration }\end{array}$ & 125 & $\begin{array}{c}157 \\
(108-324)\end{array}$ & $\begin{array}{c}832 \\
(327-1710)\end{array}$ & $\begin{array}{c}409 \\
(299-518)\end{array}$ & $\begin{array}{c}1298 \\
(820-1670)\end{array}$ \\
\hline $\mathbf{V}$ & Normal & 10 & $\begin{array}{l}\text { Stock } \\
\text { Ration }\end{array}$ & 140 & $\begin{array}{c}48 \\
(39-63)\end{array}$ & $\begin{array}{c}183 \\
(135-227)\end{array}$ & & \\
\hline
\end{tabular}

* Range of values in parentheses.

(Group II). The ingestion of the cholesterolcholate supplement did not otherwise appear grossly to affect the nephrotic state of the rats of Group III.

\section{DISCUSSION}

The present finding that the hypercholesteremia of the nephrotic rat occurs in the complete absence of dietary lipid is in accord with our earlier observation (2) that there is no increase in the rate of intestinal absorption of cholesterol in this disorder. In view of the fact that there also does not appear to be any increase in the rate of endogenous manufacture of cholesterol by the liver (3), it appears that the hypercholesteremia can only be due to a failure primarily of the liver to remove plasma cholesterol at its usual rate (9). In confirmation of this latter view is the present observation that additional intestinal absorption of cholesterol (8) by cholesterol-cholate feeding leads to a greater retention of cholesterol in plasma of nephrotic rats than in that of normal rats. The disorder then appears to be one in which cholesterol is "trapped" in plasma. Whether the excess cholate in plasma also observed in this sydrome $(9,10)$ causes the hypercholesteremia, as it was found to do in biliary obstruction (11), or whether it simply intensifies the degree of hypercholesteremia cannot be stated with certainty at this time. The tendency of the remainder of the lipid component of plasma to behave exactly as cholesterol does in all of these studies of course suggests that the mechanism responsible for the plasma retention of the latter is also operative in the retention of the former.

\section{SUMMARY}

The development of hyperlipemia and hypercholesteremia was studied in nephrotic rats fed a normal diet, a ration free of fats and sterols, and

TABLE II

Effect of excess dietary cholesterol upon hyperlipemio and hypercholesteremia of nephrotic rats

\begin{tabular}{|c|c|c|c|c|c|c|}
\hline \multirow[b]{2}{*}{ Group } & \multirow[b]{2}{*}{ Type of rat } & \multirow{2}{*}{$\begin{array}{l}\text { No. of } \\
\text { rats }\end{array}$} & \multirow[b]{2}{*}{ Diet } & \multirow{2}{*}{$\begin{array}{c}\text { Average } \\
\text { weight } \\
\text { (Gm.) }\end{array}$} & \multicolumn{2}{|c|}{$\begin{array}{c}\text { Averace plasma concentration } \\
(m g . / 100 \text { cc. }) t\end{array}$} \\
\hline & & & & & Cholesterol & Total lipids \\
\hline II & Nephrotic & 8 & $\begin{array}{l}\text { Stock } \\
\text { Ration }\end{array}$ & 125 & $\begin{array}{c}157 \\
(108-329)\end{array}$ & $\begin{array}{c}832 \\
(327-1710)\end{array}$ \\
\hline III & Nephrotic & 5 & $\begin{array}{l}\text { Stock and } \\
\text { Sterols* }\end{array}$ & 150 & $\begin{array}{c}446 \\
(328-653)\end{array}$ & $\begin{array}{c}1307 \\
(855-2180)\end{array}$ \\
\hline IV & Normal & 6 & $\begin{array}{l}\text { Stock and } \\
\text { Sterols* }\end{array}$ & 135 & $\begin{array}{c}138 \\
(68-255)\end{array}$ & $\begin{array}{c}645 \\
(400-800)\end{array}$ \\
\hline V & Normal & 10 & $\begin{array}{l}\text { Stock } \\
\text { Ration }\end{array}$ & 140 & $\begin{array}{c}48 \\
(39-63)\end{array}$ & $\begin{array}{c}183 \\
(135-227)\end{array}$ \\
\hline
\end{tabular}

* 2 per cent cholesterol and 1 per cent cholic acid.

$\dagger$ Figures in parentheses refer to range of values. 
a ration supplemented with cholesterol and cholic acid. The results indicate that the development and maintenance of hyperlipemia and hypercholesteremia in the nephrotic rat are of endogenous origin and that increased retention of lipids occurs in the plasma of such rats. It is suggested that the hyperlipemia and hypercholesteremia of nephrotic rats are due to a diminished rate of elimination of lipids from their plasma.

\section{REFERENCES}

1. Heymann, W., and Lund, H. Z., Nephrotic syndrome in rats. Pediatrics, 1951, 7, 691.

2. Rosenman, R. H., Friedman, M., and Byers, S. O., The intestinal absorption of cholesterol in nephrotic rats. Circ. Res., 1954, 2, 256.

3. Byers, S. O., Friedman, M., and Rosenman, R. H., The hepatic synthesis of cholesterol in nephrotic rats. Am. J. Physiol., In Press.

4. Byers, S. O., Friedman, M.; and Michaelis, F., Observations concerning the production and excretion of cholesterol in mammals. I. Plasma cholesterol after bile duct ligation and free cholesterol injection. J. Biol. Chem., 1950, 184, 71.
5. Bragdon, J. H., Colorimetric determination of blood lipides. J. Biol. Chem., 1951, 190, 513.

6. Page, I. H., and Brown, H. B., Induced hypercholesterolemia and atherogenesis. Circulation, 1952, 6, 681 .

7. Rosenman, R. H., Byers, S. O., and Friedman, M., Role of cholate in dietary-induced hypercholesteremia of rats and rabbits. Am. J. Physiol., 1953, 175, 307.

8. Friedman, M., Byers, S. O., and Shibata, E., Observations concerning the production and excretion of cholesterol in mammals. X. Factors affecting the absorption and fate of ingested cholesterol. J. Exper. Med., 1953, 98, 107.

9. Byers, S. O., Friedman, M., and Rosenman, R. H., Review: On the regulation of blood cholesterol. Metabolism, 1952, 1, 479.

10. Rosenman, R. H., Friedman, M., and Byers, S. O., Observations concerning the cholate: cholesterol relationship in clinical and experimental nephrosis. J. Clin. Invest., 1953, 32, 121.

11. Friedman, M., and Byers, S. O., Production and excretion of cholesterol in mammals. VI. Bile acid accumulation in production of hypercholesteremia occurring after biliary obstruction. Am. J. Physiol., 1952, 168, 292. 